\title{
STRATEGIC FLEXIBILITY AND ORGANIZATIONAL RESILIENCE OF WOMEN ENTREPRENEURS' IN AFRICA DURING THE COVID-19 PANDEMIC
}

\author{
DOI: 10.17261/Pressacademia.2020.1324 \\ RJBM- V.7-ISS.4-2020(7)-p.277-287 \\ Chioma Onoshakpor ${ }^{1}$, Abasiama Etuknwa², Nagmeldin Karamalla-Gaiballa ${ }^{3}$ \\ ${ }^{1}$ Robert Gordon University, Aberdeen Business School, UK. \\ chiomamasi@yahoo.com. ORCID: 0000-0003-4092-100X \\ ${ }^{2}$ University of Huddersfield and Swiss Re, UK. \\ smbassie@gmail.com. ORCID: 0000-0003-0370-9659 \\ ${ }^{3}$ University of Commerce and Services, Poznan, Poland. \\ Karamalla@gmail.com. ORCID:0000-0001-7613-3334
}

Date Received: October 11, 2020

Date Accepted: December 15, 2020

\section{To cite this document}

Chioma, O., Abasiama, E., Gaiballa, N.G., (2020). Strategic flexibility and organizational resilience of woman entrepreneurs" in Africa during the Covid-19 pandemic. Research Journal of Business and Management (RJBM), V.7(4), p.277-287.

Permanent link to this document: http://doi.org/10.17261/Pressacademia.2020.1324

Copyright: Published by PressAcademia and limited licensed re-use rights only.

\begin{abstract}
Purpose- The focus of this paper was on role of strategic flexibility in the actualization of organizational resilience of women entrepreneurs' in Africa during the COVID-19 pandemic.

Methodology- In this study, the content bothered primarily on the experiences of women entrepreneurs within Africa - their constraints, challenges and set-backs as well as their opportunities and resilience in this COVID-19 crisis period. Scenarios were drawn from three key nations in Africa - (a) South-Africa, (b) Sudan, and (c) Nigeria. These three offered detailed evidence of the contextual factors and values that shape women entrepreneurs' actions and tendencies within their various societies and communities.

Findings- Supportive evidence also showed that the strengthening of networks, relationships with stakeholders and the emphasis on information technology advanced the organizations options and provided women entrepreneurs with various advantages in terms of information access, funding, support (social and financial) and knowledge sharing.

Conclusion- On the basis of this observation, it was affirmed that strategic flexibility is essential for the actualization of organizational resilience. Its change driven value for learning and relationships are imperative for the survival and success of women entrepreneurs in Africa.
\end{abstract}

Keywords: Strategic flexibility, women entrepreneurs, organizational resilience, Africa, COVID-19 JEL Codes: L26, E32, E02

\section{INTRODUCTION}

The recent COVID 19 pandemic, has not only revealed the unpredictable nature of the business environment, but has also demonstrated that change is indeed inevitable. This noted inevitability of change; particularly that which impacts on the economic activities of societies; is such that places a premium on organizational resilience. To survive and remain competitive, organizations are expected to be able to cope during turbulent times and to be consistent in their service offerings (Dartey-Baah, 2015; Linnenluecke.2015). This requires the structuring of organizational features that effectively support innovation, development and adaptability; all of which are hinged on the organization's capacity for strategic flexibility during change events (Asikhia, 2020). Studies suggest that the key to sustained operations and business continuity during periods of turmoil lies in the development of options advanced prior to such periods; as well as the organizations ability to identify and latch on to existing as well as emerging opportunities during such periods of turmoil (Shokouhi \& Ghafari, 2015; Wei, Yi \& Guo, 2014; Asikhia, 2020). This observed 
imperative of strategic flexibility is more so important for women entrepreneurs in Africa, given its implications for the resilience and continuity of their business ventures.

The concept of entrepreneurship builds on venture creation through creativity and innovation (Nieman \& Nieuwenhuizen, 2014; Balhara \& Singh, 2015). Most importantly, the entrepreneur is considered as one who is able to capture market opportunities based on the newness or uniqueness of their ideas and their capacity to sell such ideas. Within Africa, there has been a noted spike in entrepreneurship activities which according to studies (Nieman \& Nieuwenhuizen, 2014; Manerkar, 2015; Matsoso \& Iwu, 2015) is driven by the reported challenges of employment, poverty and emerging markets due to the increase in population and changing demography. While the challenges of entrepreneurship in Africa are commonly experienced by all groups and category of persons involved in such related activities, Nxopo and Iwu (2015) argued that women entrepreneurs are most susceptible and vulnerable during times of change. According to Nxopo and Iwu (2015), context-based militating obstacles with regards to culture, norms, inequality and poor access to education are some of the factors which negatively influence the outcomes of women entrepreneurial actions. Nxopo and Iwu (2015) and Deborah, Wilhelmina, Oyelana and Ibrahim (2015) also observed that while in the Western world women entrepreneurs are more confident and engage in ventures such as hotel management, health, ICT and tourism services, the scenario in Africa is different as existing societal frameworks often emphasized on supportive family roles thus most women are engaged in subsistence forms of entrepreneurship such as chicken farming, crafts, sewing and soap-making.

Subsequently, Malhan (2015) opined, that despite the observed context-based challenges of women entrepreneurs in Africa, reports account for a good number of growth in recent years in women entrepreneurship in sectors ranging from the oil and gas, to the cosmetic industry. Yet still a lot is required in building and strengthening women's resolve and confidence in entrepreneurship. This is true, especially given the COVID 19 pandemic experience and its negative impact on businesses. Linnenluecke (2015) argued that one of underlying features of successful entrepreneurship is its resilience; which not only ensures the survival of the business but also enhances the confidence of the entrepreneur. Burnard and Bhamra (2015) noted that resilience in business is hinged primarily on the knowledgeability of the context and the development of functional robustness. These according to Burnard and Bhamra (2015) are imperative for effectively aligning and matching product or service offerings with the shifts or dynamics of the context of the entrepreneur. Change as earlier noted is inevitable, but as studies Hock and Clau (2016) have revealed, the strategic flexibility of businesses such as reflected in the development of strategic choices and alternatives, resource control and application and business network development, are such that provide the entrepreneur with a pool of opportunities, options and avenues for new markets, increased servicing options as well as adaptive mechanisms which in turn enhance the resilience of businesses.

Studies (Liliane \& Peter, 2015; Balhara \& Singh, 2015) suggest that women entrepreneurs are key to growing the productivity and unlocking the potentials of most African economies and it is for this reason that a review of recent literatures reporting on resilient strategies adopted by these gender category of entrepreneurs during the pandemic (COVID-19) was conducted to understand both the impact and the key successful business approaches adopted by these women for the survival of their businesses. By studying these effective resilience business models, this study will address the current gap in knowledge in this area, thus advancing scholarly knowledge on the role of women entrepreneurs in buffering the negative effects of unexpected events such as COVID -19. It would also become useful for failing entrepreneurs in adopting more effective strategic approaches to resisting adverse crisis events and securing the future of their businesses.

The rest of this article will follow this sequence. Firstly, a review of literature on Female entrepreneurs in Africa will be made, then the concept of strategic flexibility and the concept of organizational resilience will be explored. Next, a detailed review of women entrepreneurs in Africa and their response to Covid-19 pandemic will follow, case studies of the scenario in South-Africa, the scenario in Sudan, and the scenario in Nigeria comes next, we draw upon some conclusions and lastly make recommendations for strategies going forward.

\section{WOMEN ENTREPRENEURS IN AFRICA}

The concept of entrepreneurship is quite wide but primarily denotes the calculated effort in establishing new ventures through the creation of value aimed at generating profit (Nieman \& Nieuwenhuizen, 2014). All entrepreneurial activities are purposeful. Ideally, entrepreneurial actions are often based on market or social gaps, with the aim of advancing solutions to such gaps in a manner that yields benefit through its capacity to addresses particular market problems or satisfaction gaps (Gallindoa \& Mendez, 2014). This way, one could describe entrepreneurship as anchored on the opportunities inherent within the context of the entrepreneur - hence, the context defines what is tenable, acceptable and appropriate. Within African societies and peoples, one finds that factors such as tradition, culture and religion play significant roles in the moulding of relationships, and social realities. This according to Nwagbara (2012) is premised on the high level of superstition and historical values that bind and define the 
various ethnic groups within African societies. One of such is the paternalistic value and consideration of men over women. Apart from the limitations in terms of choice constraints and subservience this has placed on the African woman, there is also the issue of inequality in terms of access to education and other opportunities (Nxopo \& Iwu, 2015; Malhan \& Ishita, 2015)). These factors have for centuries shaped the life world of women in Africa to a considerable extent, impact on their entrepreneurial tendencies and behaviour.

Entrepreneurial actions have over the years served as a basis for poverty alleviation, employment and also as a means for improving one's social status (especially given the title of CEO, Director etc) (Baumol, 2014; Galindoa \& Mendez, 2014). While the motivation for entrepreneurship varies, Matsoso and Iwu (2016) observed that for African women within the context of Africa, it is more of a survival action rather than some self-actualization process. An understanding of the entrepreneurial behaviour of African women as earlier noted is hinged on knowledge about their context. So also their choices of entrepreneurial ventures are defined on the basis of their predefined roles within the context of their families, culture groups and society as a whole. Yet still, studies have identified the emergence of global markets as necessitating cultural dilutions which so far have advanced both positive and negative outcomes for most African nations (Gupta, 2020; Desppande, Kibe \& Kaaria, 2020). One of such positive outcome is women's increased awareness, support and recognition as viable and productive resources of their nations (Liliane \& Peter, 2015). This growing recognition and advocacy for women has spurred on changes in their welfare and development and so far, has also contributed immensely to their confidence and increased tendency for entrepreneurial behaviour, not only as a means for supporting their families, but as a way of establishing their identities and enhancing their status as significant actors within their societies.

\section{Figure 1: Top Ranking African Countries with Percentage Population of Women in Entrepreneurship}

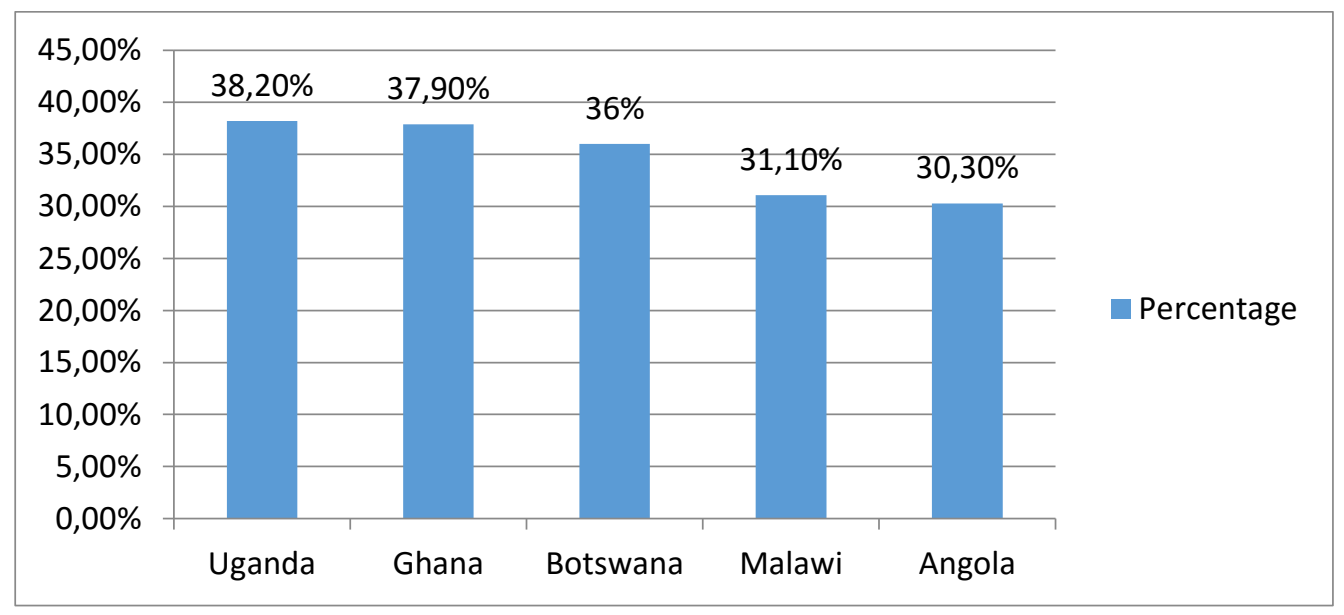

Source: Mastercard (2019)

The distribution (figure 1) for the African countries with the highest number of women entrepreneurs reveals Uganda as having the highest number of female owned businesses. Interestingly, this also applies on a global scale which ranked these five African countries as having the highest percentage of women entrepreneurs as at 2019 (Mastercard, 2019). The distribution also demonstrates a growing recognition and tolerance for women in business and as viable human resources in the growth of economies. However, despite these positive ratings, in most other African countries, policies and regulatory frameworks yet hinder women's entrepreneurial growth potentials (AFAWA, 2000). Entrepreneurship researchers have identified various environmental factors, which some have tagged external factors. Principal among the factors identified are influences of firms, influences of markets (Thorntorn, 1999); public policies (Dobbin \& Dowd, 1997); regulations and policies (Baumol, 1990) and physical infrastructure (Agboli \& Ukaegbu, 2006). Female entrepreneurs in Nigeria face environment challenges such as: lack of micro finance factors, marginalization, self-confidence, poor access to micro credit revolving schemes, poor investment opportunities in developing women micro small and medium scale business and rigid and male dominated market conditions (Hammawa and Hashim, 2016). 
Hammawa and Hashim (2016) also suggest that though women start their business at a micro and informal level, they will require markets to sustain and grow their businesses. Finding these markets for female entrepreneurs may arguably be daunting considering their status as mothers. They will rather restrict their market close to their homes in order to combine their domestic responsibilities with their productive entrepreneurial engagements making access to market a challenging one. In the Report by GEM 2017, women entrepreneurship survey, Wholesale/retail trade accounts for about $60 \%$ of female entrepreneurial activity across the 6 geographical zones considered in this survey. Across the entire population sample, female entrepreneurs are $16 \%$ more likely than men to be starting wholesale/ retail businesses. Adversely, Women entrepreneurs are less likely to be present in the information and communications technology (ICT) sector as fewer than $2 \%$ are starting ICT businesses. Female entrepreneurs dominate this business sector compared to men at all development levels as women are two and one-fourth times more likely than men to be starting in this sector.

To keep pace with the ongoing transformation of the business world, women are in constant need of the necessary training and qualification, and the quality of formal or informal bodies interested in training businesswomen in Africa is important; for instance in Sudan, training programmes for these businesswomen must include courses in planning, marketing skills, time management, etiquette, and protocol. But with the spread of the COVID-19 pandemic throughout the world, many businesswomen in Africa have found it more difficult than before to access this training even from afar. From this position, it is therefore evident that to survive and grow their businesses, it is important that these women must focus on developing their options and by that improving on their strategic flexibility. Not only would this offer them a range of options and alternatives during crisis periods such as expressed by the COVID-19 pandemic, but it would increase their chances of survival and business continuity.

\section{THE CONCEPT OF STRATEGIC FLEXIBILITY}

The concept of strategic flexibility builds on the features or attributes of the organization that allow for its effective adapting of resources and processes to match the imperatives of its environment so as to achieve long-term goals. In other words, while the organization's goals may be stable, its behaviour and attributes may change from time to time, basically in line with the fluctuations and dynamics of its environment (Cingoz \& Akodgan, 2013; Wei, et al, 2014). Strategic flexibility differs from concepts such as adaptation in the sense that while adaptation reflects the capacity for aligned individual and organizational actions with the changes or development within their context, strategic flexibility captures the alternatives and availing pool of options open to the organization as a result of its relationships, competencies and technology. Kamasaka, Yavuzb, Karaguillec and Agcad (2016) opined that strategic flexibility derives from the organization's relationship with and management of its stakeholders, its access to funds or finance when required, its level of embeddedness, its capabilities in terms of skills and knowledge and also its structural form and decision-making processes (Ibrahimpour-Azbari, Nopasand-Asil, Saravani, 2015). It is as such a pervading factor as it integrates all other functions, processes and levels of the organization in a systematic manner (Doroudi \& Babaei, 2016; Supeno, Sudharma, Aisiah \& Laksmana, 2015; Shokouhi \& Ghafari, 2015).

\section{THE CONCEPT OF ORGANIZATIONAL RESILIENCE}

The resilience of organizations according to studies (Pasteur, 2011; Eketu, 2015; Ahiauzu \& Jaja, 2015) is relative. The survival of organizations from this perspective is linked to the suitability of its policies and behaviour in addressing the demands and development of its market. While there appears to be congruence in the adoption of measurement factors such as situation awareness, adaptability, agility, robustness etc. by most researchers (Wright, Kiparoglou, Williams \& Hilton, 2012; Linnenluecke, 2015), however, these only are patterned towards the unique experiences of organizations within their particular environment or contexts. Eketu (2015) opined that organizational resilience is also a deliberate process and requires conscious effort and planning on the part of the business owner or the leader of the organization is ensuring considerable flow between organizational functions and the upheavals of its environment. The development of organizational resilience is such that is also premised on the learning capability of the organization and the reconfiguration of organizational forms when necessary (Valikangas, George \& Romme, 2012). According to Wright et al (2012), entrepreneurs that have the capacity to tie their functions to the trends and gaps in their markets have a higher tendency for survival - this involves substantial expressions of innovativeness in their development of services to suit evident satisfaction gaps. However, innovativeness is distinct from resilience, because one could be innovative and yet fail in their pace with change.

It is also imperative to note that while organisational resilience has in recent times gained recognition; its conceptualisation is still in its infancy (Duchek, 2019). Hence, there are no clear rule-book of what it means in practical terms and how it is implemented. This lack of clarity on how to conceptualise organisational resilient approaches to buffering unexpected events informed Duchek's (2019) process-based study which identified three successive resilience stages; anticipation, coping and resilience. However, given how sudden the coronavirus outbreak was, and its potential threat to the survival of businesses, it is safe to wonder if these 
women entrepreneurial businesses had before time anticipated an event such as this, and developed a resilience capacity to enable them adequately respond to, and if their remedial approaches reflect Duchek's (2019) three resilience stages. However, many studies assert that organisational resilience in itself is a defensive approach to resisting adversity and ensuring organisations thrive in the face of it (Duchek, 2019).

\section{WOMEN ENTREPRENEURS IN AFRICA AND RESPONSE TO THE COVID-19 PANDEMIC}

Strategic flexibility facilitates the cushioning of effects which otherwise, may have been devastating for the organization. This is because it advances options and alternatives which enable the organization's switch and adoption of approaches which ensure its survival and continuity. Ozili (2020) argued that the onslaught of the COVID-19 pandemic is such that primarily cripple's businesses on a physical plane and by that, traditional forms of exchanges which involves the physical interaction between buyers and sellers. However, its impact on other key industries such as transportation, tourism and manufacturing may also have overlapping effects on other industries - for one, the closure of borders was noted to impact severely on the cost of raw materials and food items within most African countries (Akanni \& Gabriel, 2020; Ohia, Bakarey \& Ahmad, 2020). One of the most affected was the tourism industry with most hotels shut down following government instructions in line with controlling the spread of the virus. In view of these factors, three cases scenarios are presented herein, in line with the experiences of women entrepreneurs and the COVID-19 pandemic in Africa. These include case scenarios in South Africa, Sudan and Nigeria.

\section{THE SCENARIO IN SOUTH-AFRICA}

In the current stage of the Covid-19 pandemic's evolution and South Africa's contagion path, the country faces difficult policy choices. The only tool currently available to mitigate the demographic effects of Covid-19 is some form of lockdown of households and non-essential producers to reduce contagion through breaking existing social and economic forms of contact. Such measures impose a severe negative shock on the economy, with immediate loss of economic activity followed by medium-term and longterm economic effects. Policy makers must balance the positive health effects of a lockdown against the economic costs. To fight the spread of Covid-19, President Ramaphosa declared a National State of Disaster with countermeasures on 15 March, and then a three-week lockdown (national stay at home order) on March 23 rd, but effective 27 March 2020. These measures are likely to buy South Africa time to develop and then implement a long-run response to Covid-19. The three-week lockdown will impose immediate economic costs, but the pandemic is certain to impose significant human and economic costs well into the future. In South Africa, according to a policy briefing Afawa, (2020) Whole Sale/Retail sector had a large decline in operations (30-60\%). This is the sector where mostly female entrepreneurs operate in (GEM, 2017)

\section{THE SCENARIO IN SUDAN}

Many Sudanese businesswomen have difficulty obtaining the right Internet connection due to the high cost and weak communication networks in Sudan. They also lack the necessary equipment and knowledge to deal with computers, due to the lack of education in this field and the lack of sufficient time to do so, because most businesswomen in Sudan have other tasks related to raising children and performing other domestic duties that are required by religious and social obligations. Also, many husbands exercise male authority and prevent their wives from working, and thus they devote themselves to housework and childcare. It is also difficult to activate the role of businesswomen in internal and external exhibitions, conferences, or festivals and to participate in many of them directly now in light of the outbreak of the COVID-19 pandemic (Welsh, Memili, Kaziak, \&Ahmed, 2013).

Ninety-three percent of ready-made garment factories, for example, are owned by Sudanese women (according to the Sudanese Ministry of Trade and Industry), and there are women who work in fields previously inaccessible to women and have succeeded in them, such as in the field of raising non-pet animals like lions and tigers, the field of manufacturing honey bees, and the field of scrap iron and steel trade in industrial areas. However, there are no real figures or studies on the extent of these businesswomen's influence on the Sudanese national economy. Only one study has been conducted on female entrepreneurs in North Sudan, which was more than two decades ago. Pitamber (1999) found that most female entrepreneurs in Sudan are 20-49 years of age and are married with four tofive children. The vast majority (90\%) lack computer skills. The majority of these entrepreneurs had at least a high school degree, $97 \%$ started their businesses themselves, and their businesses are primarily beauty salons, food and cookies, and hand crafts. Three percent had permanent locations in shopping centres and buildings outside the home (Welsh et al., 2013).

Likewise, laws and social and religious norms basically limit women's work, and women are sometimes beaten and humiliated by police officers and law guards. They also face bullying and sexual harassment because of their practice of professions outside the scope of what is known in society. Therefore, there is an urgent need for decision-makers in Sudan to know more about this important segment of society, the extent of its contribution to the national economy, and how to support it and protect its human 
and civil rights, especially during the COVID-19 pandemic so that all challenges can be overcome, and the problems facing the work of Sudanese businesswomen, which did not come as an opponent over the man, but for his participation to confront the economic conditions that have become burdensome for families and for integration and the formation of an addition to the Sudanese family. It appears that the major problem is the one that women workers in marginal professions face, whether in selling tea and food or domestic workers, especially since most of them are displaced from war and conflict areas and went to work for compelling reasons, including the absence of the breadwinner, until they face daily persecution by means of the authorities confiscate their tools, unfair trials with fines, and prosecute them with social stigma (Said \& Enslin, 2020).

Sudanese women working in the productive business sector have many roles and gradations in their levels, and there are a number of interfaces that support them to move up the ladder of development in this field. One of these interfaces is the Sudanese Centre for the Development of Businesswomen, which is the first of its kind in Sudan as a specialized centre to empower women economically and develop women leaders, inclusive decision-makers, and innovative opportunities. The council was established in October 2009 and has helped many women develop their businesses, contributed socially, and participated internally and externally on behalf of Sudan in many activities. On 25August 2017, Sudan launched the Union of Businesswomen in the countries of the COMESA group, which represents the common regional market for eastern and southern Africa (Alhaj, 2011).

Currently, Sudanese businesswomen are not aware of their rights, especially in marginal areas, especially since Sudan passed a law years ago aimed at protecting working women, not chasing them or imposing fees on them, and even exempting them from taxes. The same law stipulates the formation of a body whose mission is to provide the necessary funding for women to be able to start their own businesses. From this standpoint, businesswomen in Sudan face three main challenges: mastering work, removing the mental image of Sudanese women, and providing financing for projects.

\section{THE SCENARIO IN NIGERIA}

In the case of Nigeria, Alozie, Ideh and Ifelunini (2020) observed that MSME's account for about $96 \%$ of businesses and provide $54 \%$ of employment and labour utilization and contributed around half of the GDP. Empirical studies show that larger proportion of the SME's in the country is ill-equipped to handle a pandemic crisis of this magnitude, therefore the government should focus its intervention programmes and stimulus packages to MSMEs and agric-entrepreneurs for survival and continuity. According to (NBS, 2017) unemployment rate was $23.1 \%$ and underemployment rose to $16.6 \%$, with over 20 million Nigerians currently unemployed in 2017 pre-COVID 19 periods. With the looming crisis that will arise from the pandemic, this figure will increase significantly. The government of Nigeria has expressed concerns that about 39.4 million Nigerians may lose their jobs as a result of the COVID-19 outbreak before the end year 2020 (Olaniyi M., Iloani F., and Usman S.U, 2020).

Figure 2: Percentage Distribution for Sources of Women Entrepreneur Capital in Nigeria

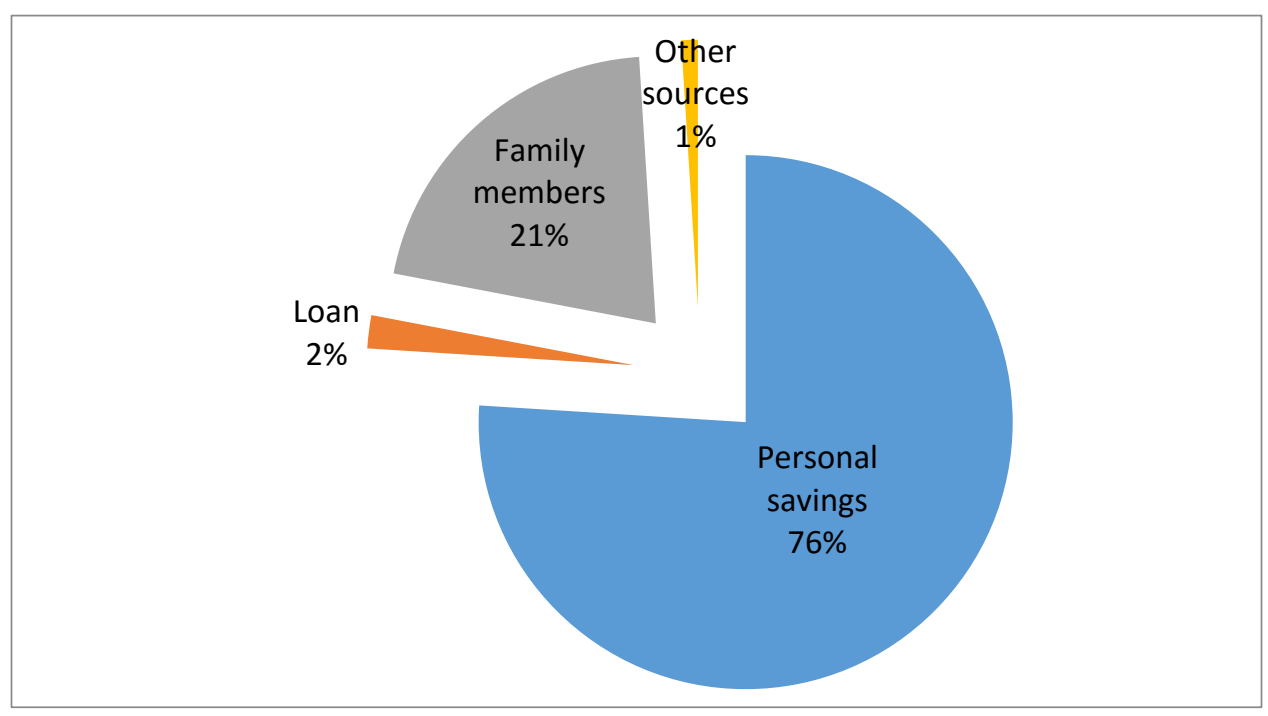

Source: OECD Handbook for Internationally Comparative Education Statistics, 2018. 
The distribution (Figure 2) for the percentage distribution for the sources of women entrepreneur capital in Nigeria, reveals that a dominant number of these women draw their capital from their personal savings and reserves (76\%). The least source (others) captures other categories not reflected in assessment but with loans amounting to only $2 \%$ and family members amounting to $21 \%$. The figure demonstrates a high level of self-reliance possibly as a result of poor access to other forms of support. However, this places a serious burden on these women and suggests either an absence of policies and frameworks within the country which supports and funds such ventures or the poor implementation and monitoring of such policies and frameworks.

Understanding the strategic efforts of women entrepreneurs has become important because women are more likely to be found in service industries or informal sectors that have been hit the hardest during the pandemic, and they are more likely than men to be self-employed entrepreneurs (Grandy, et al., 2020). Implying that their business is their source of livelihood, hence every effort would be made for the survival of their income pool. Additionally, as the transition to remote services in these times is considered critical for the survival of small businesses, it is predicted that it would pose a unique barrier to more women than men, especially as they are less likely to be in technology-oriented sectors (Grandy, et al., 2020). Therefore, suggesting that where women are not tech-savvy, a threat to their business is imminent.

However, despite these traditional gender limitations, there is evidence showing that women have often shown to be capable of thriving against business challenges (Manolova, et al., 2020), and as such COVID-19 threats to their business may be "just another day at work" for these women. According to Cesaroni et al (2015), women entrepreneurs are more prone to adopting a more defensive approach to survival in the face of challenges compared to men's offensive approach. Grandy et al. (2020) argues that their defensive approach to crisis is as a result of women being more adversely impacted by economic downturns and natural disasters. The adverse impact of a crisis on women have been previously argued in a qualitative research conducted in 17 developing countries on how people coped with the food, fuel and financial crisis between 2008-2011 (Heltberg, et al., 2013). Findings from Heltberg et al.'s (2013) study highlighted the gender differences in the impact and coping responses to the crisis, with women often acting as shock-absorbers.

However, evidence suggests that while some businesses are successful in responding to, and surviving these unexpected events, others are not, despite being under similar circumstances (Fiksel, et al., 2015). Research on entrepreneurial resilience during challenges has previously been conducted to understand what drives entrepreneurial decisions during challenging times. Findings from one of such studies highlighted three main strategies entrepreneurs adopted in order to build the self-efficacy and resilience of businesses against adversity (Bullough \& Renko, 2013); 1. Engage in business development training, 2. Seek out networking events, special lectures and mentoring opportunities, and 3. Be active in their entrepreneurial pursuits, practice business acumen and seek feedback from those who can be objective, critical and encouraging.

Apart from the networks and ties availed through healthy stakeholders' relationships and support from customers, most African women have also been observed to shift focus in terms of marketing strategies with a growing percentage of these women now relying on social media platforms (e.g. FaceBook, WhatsApp, YouTube, Linkedln etc) for the development and maintenance of their customer base (IFC, 2020; Gupta, 2020; Empower Women, 2020). Holmes, Peterman, Sammon, Cabot and Alfers (2020) in their study noted that access to information was a vital factor which is maximized by most business women during the COVID-19 pandemic, some of such opportunities and access to funding such are as availed by the Women's Entrepreneur Finance Initiative (WE-FI) and the European Bank for Reconstruction and Development (EBRD), have helped ameliorate the challenges and set-backs posed by the COVID-19 pandemic. With the WE-FI announcing $\$ 43.3$ million funding allocation for women-led businesses and female entrepreneurs across the world; over $65 \%$ of these allocations are targeted at women entrepreneurs in developing countries affected by conflict and ravaged by the COVID-19 pandemic (WE-FI, 2020).

In the same vein, report (WE-FI, 2020; UN Women, 2020; Investing in Women, 2020) shows that the EBRD was allocated \$7.63 million for advancing women program aimed at leveraging the competitiveness and growth of women entrepreneurs within some African nations such as Morocco and Egypt. Similar efforts are also observed on the parts of other banks such as the Inter-American Development Bank, and the Islamic Development Bank. These efforts have contributed towards strengthening the resilience of women entrepreneurs in Africa and by providing a base for them to thrive during the COVID-19 pandemic. Similarly, across countries such as Nigeria, Cameroun and Senegal, studies (Adegboye, Adekunle \& Gayawan, 2020; Jacob, Abigeal \& Lydia, 2020; Ozili, 2020) suggest a high level of dependence on women collaborative efforts, associations and joint support. In Nigeria, these associations offer reprieve and access to funding for their active members and in a way serve to indemnify their members against the shock and adverse effect of the COVID-19 pandemic on their businesses. Dominant amongst these associations are the Association of Nigerian Women Business Network (ANWBN), the Nigerian Association of Women Entrepreneurs (NAWE) and the Women Entrepreneurs Association of Nigerian (WEAN). These associations offer a network of women entrepreneurs which as reported, play key roles in buffering the impact of the COVID-19 pandemic on their members. 
One finds that the development of strategic flexibility through networks is critical and essential to women's entrepreneur resilience. Not only does it offer a framework for resource sharing, it also allows for knowledge transfer and learning. Within such a period as occasioned by the COVID-19, there is the imperative for women cooperation and support mechanisms that encourage successful business model adoption and application (Holmes et al, 2020). One of the noted advantages of women entrepreneur associations is that it creates partners from otherwise would-be competitors and that way allows for interdependence and collaborative growth for all members. This way, members are privy to knowledge from more successful and resilient members within their associations. Apart from the support from family members and personal savings, the observed pooling of resources by these associations, and their coordination of members actions, regulation of prices and information transfer, create a dynamic process which effectively bridges entrepreneurial actions with the features of the environment and thus enhances resilience outcomes.

\section{CONCLUSION}

The COVID19 pandemic no doubt, as discussed, has impacted negatively and adversely on businesses, and given the vulnerability of women entrepreneurs, especially those in Africa, concerns about their resilience and survival during the period was the main focus and interest of this paper. As revealed in the case scenarios, women entrepreneurs in Africa are face with a multitude of challenges and militating factors which stem primarily from the ideologies and historical tenets that have come to shape and define their communities and societies. While recent changes necessitated by globalization have increased business opportunities and encouraged the growth in women entrepreneurs in Africa, the current surge of the COVID-19 has yet again brought to bear, the imperatives of women entrepreneur resilience through improved levels of strategic flexibility. Key amongst these as discussed, are the noted advantages of networks and women entrepreneur associations, healthy stakeholders' relationships and increased utility of information technology and online business platforms during the COVID-19 pandemic. It is on this basis affirmed that strategic flexibility is critical to the success and survival of women-owned businesses in Africa. Its focus on building and strengthening relationships presents these women entrepreneurs with a range and pool of options and support systems that facilitate increased access to information, funding, social as well as economic support and capacity development.

\section{RECOMMENDATIONS}

In view of the observed imperative of strategic flexibility for improved levels of organizational resilience of women entrepreneurs in Africa, the following recommendations are put forward:

i. More effort is required on the part of government authorities and key stakeholders in the development and support of women entrepreneur through the availing of loans, training programs and partnerships with women entrepreneur as a way of encouraging and motivating them towards entrepreneurship and at the same time equipping them with the required tools for coping and dealing with crisis situations within their environment.

ii. It is important that women entrepreneurs take advantage of the benefits and positioning that accrues from their membership of business networks which a clear purpose of offering them social and financial support. At the same time, such associations should allow for collaboration and through that knowledge sharing in which smaller or novice entrepreneurs can learn and adopt the effective practices or entrepreneurs' modules utilized by their more experienced and successful counterparts.

iii. Education is vital to the development of confidence and esteem in the African girl child. Through education, comes exposure and as such the increased tendency for financial independence, self-efficacy and self-reliance - key factors necessary for successful women entrepreneurs. It is therefore recommended that more efforts be channelled towards educating and developing the girl child within Africa and by that offering them the required levels of competence and confidence for contributing meaningfully to the economies of their nations, especially those of Africa.

\section{REFERENCES}

Adegboye, O. A., Adekunle, A. I., \& Gayawan, E. (2020). Early Transmission Dynamics of Novel Coronavirus (COVID-19) in Nigeria. International Journal of Environmental Research and Public Health, 17(9), 3054.

Afawa, 2020. Affirmative Finance Action for Women in Africa, ImpactHER and UN Women Policy Brief exposes disadvantages to women entrepreneurs in post COVID-19 era, offers solutions. https://www.afdb.org/en/news-and-events/press-releases/affirmative-finance-actionwomen-africa-impacther-and-un-women-policy-brief-exposes-disadvantages-women-entrepreneurs-post-covid-19-era-offers-solutions-36891

Agboli, M. \& Ukaegbu, C. C. (2006). Business environment and entrepreneurial activity in Nigeria: Implications for industrial development. Journal of Modern African Studies. 44(1), 1-30 
Ahiauzu, L.U.\& . Jaja, S.A. (2015). Process innovation and organizational resilience in public universities in South-South, Nigeria. International Journal of Managerial Studies and Research. Volume 3, Issue 11, pp. 102-111.

Akanni, L.O., and S. C. Gabriel. 2020. The Implication of Covid19 on the Nigerian Economy. Centre for the Study of the Economies of Africa (CSEA). http://cseaafrica.org/theimplication-of-covid19-on-the-nigerian-economy/.

Alhaj, A. (2011). An ode to the Center for Developing Businesswomen and its leadership. Sudanow-Magazine, http://sudanowmagazine.net/pageArch.php?archYear=2011\&archMonth=2\&ld=122

Alozie CE, Ideh AO \& Ifelunini I (2020). Coronavirus (COVID-19) pandemic, economic consequences and strategies for ameliorating macroeconomic shocks in Nigeria's economy.

Asikhia, O. (2010). Market-focused strategic flexibility among Nigerian banks, African. Journal of Marketing Management, 2(2), 018-028.

Balhara, S. \& Singh, A. 2015. Women entrepreneurship: A big motivation. Business and economic research, 5(2): 207-216,

Baumol WJ (2014) Stimulating growth amid recession: entrepreneurship, innovation, and the keynesian revolution. J Jpolmod 36: 629-635.

Baumol, W. J. (1990). Entrepreneurship: Productive, unproductive and destructive. Journal of Political Economy, 98, 893-921

Blair, C. 2015. Rwanda's gender gap: Banks must stop failing female entrepreneurs. https://www.theguardian.com/.../rwanda-gender-gap-banksfailing-female-entreprene

Bullough, A. \& Renko, M., 2013. Entrepreneurial Resilience during Challenging Times. Business Horizons, 56(3), pp. 343-350.

Burnard, K. \& Bhamra, R. (2011). Organisational resilience: development of a conceptual framework for organisational responses. International Journal of Production Research 49 (18), 15, 5581-5599.

Care (2020b). COVID-19 Could Condemn Women To Decades of Poverty: Implications of the COVID-19 Pandemic on Women's and Girls' Economic Justice and Rights. [online] Available at: https://insights.careinternational.org.uk/media/k2/attachments/CARE_- Implications_of_COVID19 on WEE 300420.pdf

Cesaroni, F. M., Sentuti, A. \& Buratti, A., 2015. Same crisis, different strategies? Italian men and women entre- preneurs in front of the economic recession. Journal of Research in Gender Studies, 5(2), pp. 205-331

Cingoz, A., \& Akodgan, A. A. (2013). Strategic Flexibility, Environmental Dynamism, and Innovation Performance: An Empirical Study, 9th International Strategic Management Conference, Available Online At www.sciencedirect.com

Dartey-Baah, K. (2015). Resilient leadership: A transformational-transactional leadership mix. Journal of Global Responsibility, 6(1), 99-112.

Deborah, A.E., Wilhelmina, S., Oyelana, A.A. \& Ibrahim, S.I. 2015. Challenges faced by women entrepreneurs and strategies adopted by women entrepreneurs to ensure small business success in Nkonkobe Municipality. Journal of Economics, 6(1): 37-49, Fall.

Deshpande, R., Kibe, J. and Kaaria, L. (2020). COVID-19 Exposes Risks and Opportunities in Kenya's Gig Economy. [online] www.cgap.org. Available at: https://www.cgap.org/blog/covid-19-exposes-risks-and-opportunities-kenyas-gig-economy [Accessed 8 Jun. 2020].

Dobbin, F. \& Dowd, T. J. 1997. How Policy Shapes Competition: Early Railroad Foundings in Massachusetts. Administrative Science Quarterly, 42: 501-529.

Doroudi, H., Babaei, L. (2016), A Study on the Relationship Between Strategic Planning Processes, Planning Flexibility, and Firm Performance: Considering the Mediating role of Innovation. Qom: International Conference on Economy, Management, and Psychology

Duchek, S., 2019. Organizational resilience: a capability-based conceptualization. Business Research, Volume 13, pp. 215-246

Eketu, C.A (2015). Talent Management and Sustainable Enterprise Resilience among Travel Agencies in Port Harcourt. International Journal of Business and Management, Volume III, Issue VIII.

Empower Women (2020). Empower Women - Learning Webinar: Business, Non-discrimination and Gender Equality in the Time of COVID19. [online] EmpowerWomen. Available at: https://www.empowerwomen.org/en/community/stories/2020/05/learning-webinarbusinessnondiscrimination-and-gender-equality-in-the-time-of-covid19 [Accessed 8 Jun. 2020].

Fiksel, J., Polyviou, M., Croxton, K. L. \& Prettit, T. J., 2015. From risk to resilience: Learning to deal with disruption.. MIT Sloan Management Review, Volume 56, pp. 77-86

Gajjar, G. A. 2015. Influence of women enterprise fund training program on the growth of women owned businesses in Mombasa Country, Kenya. Unpublished Masters thesis, University of Nairobi. Nairobi

Galindoa M, Mendez MT (2014) Entrepreneurship, economic growth, and innovation: are feedback e gects at work? J Jbusres 67: 825-289.

GEM, 2017. Women's Entrepreneurship 2016/2017 Report, Global Entrepreneurship Monitor. 
Grandy, G., Cukier, W. \& Gagnon, S., 2020. (In)visibility in the margins: COVID-19, women entrepreneurs and the need for inclusive recovery. Gender in Management; An International Journal.

Gupta, Y. (2020). How Social Media Is Fueling Women's Entrepreneurship in Myanmar. [online] Available at: https://www.cgap.org/blog/howsocial-media-fueling-womensentrepreneurshipmyanmar?utm source=hootsuite\&utm medium $=\& u t m$ term $=\& u t m$ content=\&utm campaign=

Heltberg, R., Hossain, N., Reva, A. \& Turk, C., 2013. Coping and Resilience during the Food, Fuel, and Financial Crises. The Journal of Development Studies, 49(5), pp. 705-718.

Hock, M., Claub, T. (2016), Knowledge Management, Strategic Flexibility and Business Model Innovation. The Proceedings of the XXVII ISPIM Conference 2016 Porto, Portugal. p19-22.

Holmes, R., Peterman, A., Sammon, E., Cabot, V.C. and Alfers, L. (2020). Gender and Inclusion in social protection responses during COVID-19. [online] Available at: https://socialprotection.org/sites/default/files/publications_files/SPACE\%20Gender\%20and\%20Inclusion_20052020v1.pdf

Ibrahimpour-Azbari, M., Nopasand-Asil, S.M., Saravani, M. (2015), Examining the effect of strategic flexibility on the firms market performance: The mediating role of mark innovation. Industrial Technology Development, 13(26), 5-6.

IFC (2020b). Uncertainty, Fear, and Coronavirus: The New Reality for Africa's Entrepreneurs. [online] www.ifc.org. Available at: https://www.ifc.org/wps/wcm/connect/news_ext_content/ifc_external_corporate_site/news+and+events/news/impact-stories/smesafricacovid19?cid=IFC_TT_IFC_EN_EXT.

Investing In Women (2020a). Innovation, reinvention and inclusion: Businesses responding to COVID-19. [online] Investing in Women. Available at: https://investinginwomen.asia/posts/innovation-reinvention-inclusion-businesses-responding-covid-19

Jacob, O. N., Abigeal, I., \& Lydia, A. E. (2020). Impact of COVID-19 on the Higher Institutions Development in Nigeria. Electronic Research Journal of Social Sciences and Humanities, 2, 126- 135.

Kamasak, R., Yavuz, M., Karagulle, A.O., Agca, T. (2016), Importance of strategic flexibility on the knowledge and innovation relationship: An emerging market study. Journal of Procedia-Social and Behavioral Sciences, 229, 126-132

Kamasaka, R., Yavuzb, M., Karagullec, A. O., \& Agcad, T. (2016). Importance of Strategic Flexibility on the Knowledge and Innovation Relationship: An Emerging Market Study, 5th International Conference on Leadership, Technology, Innovation and Business Management, Available Online At www.sciencedirect.com

Liliane, U. K. \& Peter, M. 2015. The impact of women economic empowerment projects on the socio-economic development in Rwanda: The case of Agaseke project. European Journal of Business and Social Sciences, 4(06): 59-87, September 09.

Linnenluecke, M. K. (2015). Resilience in business and management research: A review of influential publications and a research agenda. International Journal of Management Reviews, 19(1), 4-30.

Madichie, N. O. 2015. Heaven Kigali: Narratives \& Realities of an "Ethnic Minority" Woman Business Owner. Kigali: Institute for small Business and entrepreneurship.

Malhan, A. \& Ishita, M. 2015. Difficulties and challenges face by women entrepreneur in Gurgaon. International Journal of Management and Commerce Innovation, 2(2): 637-640, October.

Manerkar, G. 2015. Women entrepreneurs in Goa: Issues and challenges. Indian Streams Research Journal, 4(12):1-8

Manolova, T., Brush, C. G., Edelman, L. F. \& Elam, A., 2020. Pivoting to stay the course: How women entrepreneurs take advantage of opportunities created by the COVID-19 pandemic. International Small Business Journal: Researching Entrepreneurship, 38(6), pp. 481-491

Masa'deh, Ra'ed (2016). The Role of Emotional Intelligence in Enhancing Organizational Effectiveness: The Case of Information Technology Managers in Jordan Int. J. Communications, Network and System Sciences, 9, 234-249.

Matsoso, M.L. \& Iwu, C.G. 2016. Women and small scale entrepreneurship. In introduction to gender studies in Eastern and Southern Africa. Sense Publishers:197-213.

$\begin{array}{lllllll}\text { MIWE } & \text { Report. } & \text { (2019). } & \text { Newsroom.mastercard.com. } & \text { Retrieved } & 17 & \text { November }\end{array}$ https://newsroom.mastercard.com/eu/files/2018/03/MIWE-2018- Report.compressed.pdf

National Bureau of Statistic (NBS), 2017. Micro, Small, And Medium Enterprises (MSME) National Survey 2017 Report .

Nieman, G. \& Nieuwenhuizen, C. 2014. Entrepreneurship: A South African Perspective. 3rd ed. Pretoria: Van Schaik.

Nwagbara, U. (2012). Leading A Postmodern African Organisation: Towards A Model of Prospective Commitment. The Journal of Pan African Studies, 4(9), 67-84 
Nxopo, Z. \& Iwu, C.G. 2015. The unique obstacles of female entrepreneurship in the tourism industry in Western Cape. Unisa Press, 13(2): 55-72 OECD (2018), OECD Handbook for Internationally Comparative Education Statistics 2018: Concepts, Standards, Definitions and Classifications, OECD Publishing, Paris, https://doi.org/10.1787/9789264304444-en.

Ohia, C., Bakarey, A. S., \& Ahmad, T. (2020). COVID-19 and Nigeria: Putting the realities in context. International Journal of Infectious Diseases.

Olaniyi M., Iloani F., and Usman S.U, 2020. Nigeria: Coronavirus - 39.4 Million Nigerians May Be Jobless in 6 Months - Govt. https://allafrica.com/stories/202006120546.html

Ozili, P.K. (2020). COVID-19 in Africa: socio-economic impact, policy response and opportunities. International Journal of Sociology and Social Policy.

Ozili, P.K. and Arun, T.G. (2020). Spillover of COVID-19: impact on the Global Economy. Working paper.

Pasteur, K. (2011). From Vulnerability to Resilience, a framework for analysis and action to build community resilience. Practical Action Publishing Pitamber, S. (1999). Women traders in Omdurman, Sudan: Entrepreneurs or mere managers. Sudan Notes and Records, 3, 131

Said, I.,\&Enslin, C. (2020). Lived experiences of females with entrepreneurship in Sudan: Networking, social expectations, and family support.https://doi.org/10.1177/2158244020963131.

Shokouhi, A., Ghafari, A. (2015), Effect of Organizational Learning and Strategic Flexibility on Innovation. 1st International Conference on Management, Economy, Accounting, and Educational Science, Ayandesaz-the Research and Consulting Co

Supeno, H., Sudharma, M., Aisjah, S., \& Laksmana, A. (2015). The Effects of Intellectual Capital, Strategic Flexibility, and Corporate Culture on Company Performance: A Study on Small and Micro-Scaled Enterprises (Smes) In Gerbangkertosusila Region, East Java. International Business and Management, 11(1), 1-12

Thornton, P. H. (1999). The sociology of entrepreneurship. Annual Review of Sociology, 25, 19-46.

UN Women (2020a). Cultivating change: Women farmers in Dominica find new paths to market amidst COVID-19 shutdowns. [online] UN Women. Available at: https://www.unwomen.org/en/news/stories/2020/6/feature-women-farmers-find-paths-to-market-amidst-covid19 [Accessed 8 Jun. 2020].

Välikangas, L., Georges, L., \& Romme, A. (2012). Building resilience capabilities at Big Brown Box, Inc. Strategy \& Leadership, 40(4), 43-45.

We-Fi Secretariat (2020a). Digital finance is providing solutions to WSMEs in times of COVID crisis | Women Entrepreneurs Finance Initiative. [online] Women Entrepreneurs Finance Initiative. Available at: https://we-fi.org/digital-finance-is-providing-solutions-towsmes-in-times-of-covidcrisis/ [Accessed 8 Jun. 2020].

Wei, Z., Yi, Y., Guo, H.H. (2014), Organizational learning, ambidexterity, strategic flexibility, and new product development. Journal of Product Innovation Management, 31(4), 832-847.

Welsh, D.H.B., Memili, E., Kaziak, E., \& Ahmed, S. (2013). Sudanese women entrepreneurs. Journal of Developmental Entrepreneurship, 18(2).

Wright, C., Kiparoglou, V., Williams, M., \& Hilton, J. (2012). A framework for resilience thinking. Procedia Computer Science, 8, 45-52. 